\title{
Adsorption of Atrazine from Aqueous Solution onto Peanut Shell Activated Carbon: Kinetics and Isotherms Studies
}

\author{
Ignace Agani ${ }^{1}$, Jacques Kabiyéssi Fatombi ${ }^{1,2,{ }^{*}, \text { Nikita Topanou }^{1}, \text { Esta Abiodon Idohou }}{ }^{1}$, \\ Taofiki Aminou ${ }^{2}$ \\ ${ }^{1}$ Laboratoire de Chimie de l'Eau et de l'Environnement (LCEE), Ecole Normale Supérieure de Natitingou, UNSTIM, Natitinqou, Bénin \\ ${ }^{2}$ Laboratoire d'Expertise et de Recherche en Chimie de l'Eau et de l'Environnement (LERCEE), UAC, Cotonou, Bénin
}

\section{Email address:}

ignace.agani@gmail.com (I. Agani), jacquesfatombi@yahoo.fr (J. K. Fatombi),ntopanou12@gmail.com (N. Topanou), idohou.esta@yahoo.com (E. A. Idohou),aminoutaofiki@yahoo.fr (T. Aminou)

${ }^{*}$ Corresponding author

\section{To cite this article:}

Ignace Agani, Jacques Kabiyéssi Fatombi, Nikita Topanou, Esta Abiodon Idohou, Taofiki Aminou. Adsorption of Atrazine from Aqueous Solution onto Peanut Shell Activated Carbon: Kinetics and Isotherms Studies. American Journal of Applied Chemistry.

Vol. 8, No. 3, 2020, pp. 82-88. doi: 10.11648/j.ajac.20200803.13

Received: July 4, 2020; Accepted: July 20, 2020; Published: July 28, 2020

\begin{abstract}
In this study, the activated carbon (AC) was prepared from phosphoric acid activation of peanut shell and used as adsorbent for atrazine removal from aqueous solutions. The prepared AC was characterized by Fourier transform infrared spectroscopy (FTIR) and scanning electron microscopy (SEM) techniques. The effect of parameters such as solution $\mathrm{pH}$, contact time, adsorbent dosage and concentration of atrazine solution were studied on adsorption process. The results of characteristics study shown that the surface of $\mathrm{AC}$ was porous with numerous functional groups. The kinetic results revealed that the adsorption process was well described by the pseudo-second-order model than the pseudo-first-order model. The intraparticle diffusion model involved in the adsorption process by multi steps. The equilibrium data were in the best agreement with the Langmuir model than the Freundlich and the Temkin models. The maximum adsorption capacities calculated according to the Langmuir isotherm were $66.66,52.63$ and $48.08 \mathrm{mg} \mathrm{g}^{-1}$ at $30^{\circ} \mathrm{C}$ and at $\mathrm{pH} 5,7$ and 9 respectively. The results of this study pointed out that the activated carbon prepared from the peanut shell has strong adsorption potential toward the atrazine herbicide, hence, it could be used for efficient adsorption of pesticide residues and other hazardous pollutants from wastewater.
\end{abstract}

Keywords: Peanut Shell, Activated Carbon, Atrazine, Adsorption

\section{Introduction}

In most of West African countries, the agriculture has been modernized since last decades. Using of phytosanitary byproducts has led to an increase in agricultural yields through the fight against weeds and harmful insects [1]. Atrazine is one of the most widely used herbicides in agricultural applications. However, atrazine has also negative effects on the environment and on human health, because it is classified as carcinogenic and mutagenic compound [2]. Atrazine residues were also found in the treated soils and surface water [3]. Thus, several methods such as oxidation [4], photocatalysis [5], electrochemical [6] and adsorption [7] are used for herbicide residues removal from polluted water. Among these methods, adsorption is widely used because of its low-cost and easily application. The adsorbents mostly used are activated carbon [7, 8], graphene oxide [9], nanocomposite material [10] and others non-conventional absorbents such as Moringa oleifera seeds and tree fern [1113]. Activated carbon is mainly used as adsorbent because it presents large specific surface area and numerous pores. However, the commercial activated carbon has high cost and is difficult to regenerate. Thus, several studies have reported the development of activated carbon from agricultural waste such as date seed shells [8] and peanut husk [14]. Furthermore, in Benin, the peanut shells are abandoned in household garbage, which cause the environmental pollution. In addition, our previous work has revealed that the activated carbon obtained from peanut shells has shown high adsorption property for 2,4-dichlorophenoxyacetic pesticide [15]. This study investigates the use of activated carbon from 
peanut shells for efficient removing of atrazine from water. The prepared activated carbon was characterized by Fourier transform infrared spectroscopy (FTIR) and scanning electron microscopy (SEM). Then, the application of activated carbon for atrazine removal from aqueous solution in a batch mode was evaluated. The effects of solution $\mathrm{pH}$, concentration of adsorbate, adsorbent dose and contact time were studied. Kinetics and isotherms studies were also performed to explain the mechanism of adsorption process.

\section{Materials and Methods}

\subsection{Reagents}

$\mathrm{H}_{3} \mathrm{PO}_{4}(85 \%, \mathrm{~d}=1.71), \mathrm{HCl}(36 \%, \mathrm{~d}=1.18), \mathrm{CH}_{3} \mathrm{OH}$ $(95 \%)$ and $\mathrm{NaOH}$ were supplied from Sigma Aldrich Spain. Atrazine $\left(\mathrm{C}_{8} \mathrm{H}_{14} \mathrm{ClN}_{5}, 80 \%\right)$ was supplied by Baochen Chemical Industry, China. Peanut shells were collected from women's cooperative groups in Kouande town, Benin. For the adsorption experiments a stock solution of $500 \mathrm{mg} \mathrm{L}^{-1}$ atrazine was prepared by dissolving $312.5 \mathrm{mg}$ of atrazine in $500 \mathrm{~mL}$ of methanol. The atrazine solution with concentration range $10-100 \mathrm{mg} \mathrm{L}^{-1}$ were obtained by dilution with distilled water of the stock solution.

\subsection{Preparation of Activated Carbon}

The activated carbon was prepared according to our previous work [15]. The dried peanut shells $(0.8$ and $1 \mathrm{~mm})$ were mixed with $30 \% \mathrm{H}_{3} \mathrm{PO}_{4}$ in impregnation ratio $1: 3$ (weight of peanut shells/weight $\mathrm{H}_{3} \mathrm{PO}_{4}$ ). The obtained mixture was heated at reflux for $2 \mathrm{~h}$ and then dried at $60^{\circ} \mathrm{C}$ for $24 \mathrm{~h}$. The resulting residue was carbonized in a muffle furnace (Carbolite Scientific) at $450^{\circ} \mathrm{C}$ for $3 \mathrm{~h}$ with $10^{\circ} \mathrm{C} / \mathrm{min}$ of heating rate. The activated carbon obtained was washed several times with distilled water until neutral $\mathrm{pH}$, dried at $110^{\circ} \mathrm{C}$ for $12 \mathrm{~h}$ and then sieved before used as adsorbent.

\subsection{Characterization of Activated Carbon}

Activated carbon (AC) was characterized using FTIR and SEM methods. The characteristics of the surface functional groups of the adsorbent were determined with Fourier transform infrared spectroscopy (FTIR) using Perkin Elmer 100 Series spectrometer. The morphology of the adsorbent surface was characterized using scanning electron microscopy (SEM-FEG 1540XB).

\subsection{Batch Adsorption}

\subsubsection{Experimental Procedure}

The adsorption experiments in batch system were carried out with $50 \mathrm{~mL}$ of $50 \mathrm{mg} / \mathrm{L}$ atrazine solution. The initial $\mathrm{pH}$ of the solution was adjusted at 5 with $0.10 \mathrm{M} \mathrm{HCl}$ and 0.10 $\mathrm{M} \mathrm{NaOH}$ solutions. An amount of $0.05 \mathrm{~g}$ of $\mathrm{AC}$ was introduced into the solution and the mixture was stirred at $100 \mathrm{rpm}$ for $2 \mathrm{~h}$ and then filtered through Whatman $\mathrm{N}^{\circ} 1$ filter paper. Final concentrations of atrazine in the filtrates were quantified by measurement of the absorbance of filtrate at
$221 \mathrm{~nm}$ wavelength using UV-Vis spectrophotometer (VWR 1600 PC). The effects of solution $\mathrm{pH}(2.0-10.0)$, adsorbent dose $(0.01-0.10 \mathrm{~g})$, atrazine concentration $\left(10-100 \mathrm{mg} \mathrm{L}^{-1}\right)$ and contact time $(0-120 \mathrm{~min})$ were studied on the adsorption process. The absorption capacity $\mathrm{q}_{\mathrm{t}}(\mathrm{mg} / \mathrm{g})$ of $\mathrm{AC}$ and the removal percentage of atrazine (RE\%) were calculated using the following expressions:

$$
\begin{gathered}
q_{t}=\frac{\left(C_{0}-C_{t}\right) V}{W} \\
R E(\%)=\frac{100\left(C_{0}-C_{t}\right)}{C_{0}}
\end{gathered}
$$

where $\mathrm{Co}$ and $\mathrm{Ct}(\mathrm{mg} / \mathrm{L})$ are the initial and final concentration of atrazine respectively, $\mathrm{V}(\mathrm{L})$ is the volume of the atrazine solution and $\mathrm{W}(\mathrm{g})$ is the weight of $\mathrm{AC}$ used.

\subsubsection{Kinetic Study}

The study of adsorption kinetic was performed using pseudo-first-order [16], pseudo-second- order [17] and intraparticle diffusion [18] models. The expressions of kinetic models are presented as follows:

$$
\begin{gathered}
\text { Pseudo-first-order: } \ln \left(q e-q_{t}\right)=\ln q_{e}-k_{1} \cdot t \\
\text { Pseudo-second-order: } \frac{t}{q_{t}}=\frac{1}{k_{2} \cdot q_{e}{ }^{2}}+\frac{1}{q_{e}} t \\
\text { Intraparticle diffusion: } q_{t}=k_{i d} \cdot t^{1 / 2}+C
\end{gathered}
$$

where $\mathrm{q}_{\mathrm{t}}$ and $\mathrm{q}_{\mathrm{e}}\left(\mathrm{mg} \mathrm{g}^{-1}\right)$ are the adsorption capacities at time $\mathrm{t}$ and at equilibrium respectively, $\mathrm{k}_{1}\left(\mathrm{~min}^{-1}\right)$ is the rate constant of the pseudo-first order model, $\mathrm{k}_{2}\left(\mathrm{mgg}^{-1} \mathrm{~min}^{-1}\right)$ is the rate constant of the pseudo-second-order model, $\mathrm{k}_{\mathrm{id}}\left(\mathrm{mgg}^{-1} \mathrm{~min}^{-1 / 2}\right)$ is the rate constant of the intraparticle diffusion model, $\mathrm{C}$ $\left(\mathrm{mg} \mathrm{g}^{-1}\right)$ is the intercept related to the boundary layer effect and $\mathrm{t}$ is the contact time (min).

\subsubsection{Adsorption Equilibrium Isotherms}

The equilibrium data were described using the Langmuir [19], Freundlich [20] and Temkin [21] isotherms. The linear forms of isotherms are written as follows:

$$
\begin{gathered}
\text { Langmuir: } \frac{C_{e}}{q_{e}}=\frac{1}{q_{m} K_{L}}+\frac{C_{e}}{q_{m}} \\
\text { Freundlich: } \ln q_{e}=\ln K_{f}+\frac{1}{n} \ln C_{e} \\
\text { Temkin: } q_{e}=B \ln A_{T}+B \ln C_{e}
\end{gathered}
$$

where $\mathrm{q}_{\mathrm{m}}(\mathrm{mg} / \mathrm{g})$ is the maximum adsorption capacity, $\mathrm{K}_{\mathrm{L}}$ $(\mathrm{L} / \mathrm{mg})$ is the constant of the Langmuir isotherm, $\mathrm{K}_{\mathrm{f}}(\mathrm{mg} / \mathrm{g}$ $\left(\mathrm{L} / \mathrm{mg}^{-1}\right)$ and $\mathrm{n}$ are the parameters of the Freundlich model, $\mathrm{R}=8.31 \mathrm{~J} / \mathrm{K} / \mathrm{mol}$ is the gas constant, $\mathrm{T}(\mathrm{K})$ is the absolute temperature, $\mathrm{b}_{\mathrm{T}}\left(\mathrm{J} \mathrm{mol}^{-1}\right), \mathrm{A}_{\mathrm{T}}(\mathrm{L} / \mathrm{mg})$ and $\mathrm{B}\left(B=\frac{R T}{b_{T}}\right)$ are the parameters of Temkin isotherm.

Langmuir isotherm is characterized by the separation factor $\mathrm{R}_{\mathrm{L}}$ expressed as follow:

$$
R_{L}=\frac{1}{1+K_{L} C_{0}}
$$

If $\mathrm{R}_{\mathrm{L}}=0$, the adsorption process is irreversible, normal if 
$0<\mathrm{R}_{\mathrm{L}}<1$, linear if $\mathrm{R}_{\mathrm{L}}=1$ and unfavorable if $\mathrm{R}_{\mathrm{L}}>1$.

\section{Results and Discussion}

\subsection{Characteristics of Activated Carbon}

Figure 1A shown the FTIR spectrum of AC. The results revealed that the broad band observed at $3436 \mathrm{~cm}^{-1}$ may be attributed to the vibration of the $\mathrm{O}-\mathrm{H}$ group. The peaks appeared at $1689 \mathrm{~cm}^{-1}$ and $1162 \mathrm{~cm}^{-1}$ were assigned to CO

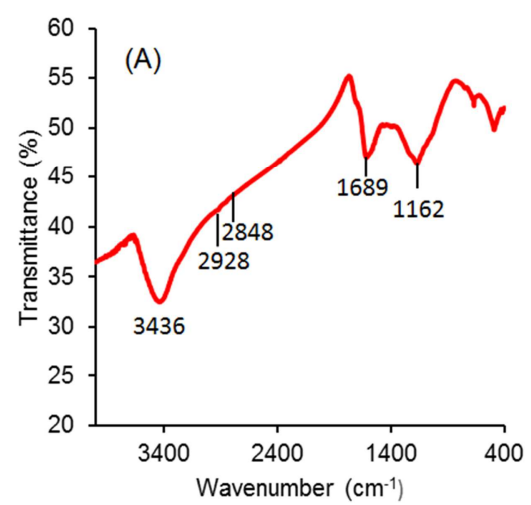

stretching vibration in carbonyl, lactonic and carboxyl functional groups [8]. The peaks at $2848 \mathrm{~cm}^{-1}$ and $2928 \mathrm{~cm}^{-1}$ were characteristics to the stretching vibration of $\mathrm{C}-\mathrm{H}$ in aromatic rings from AC lignin content [15].

The Figure $1 \mathrm{~B}$ presented the scanning electron micrograph of AC with $1.46 \mathrm{kx}$ magnification. The SEM image revealed that the AC surface is rough with numerous pores that could favor the adsorption of atrazine molecules.

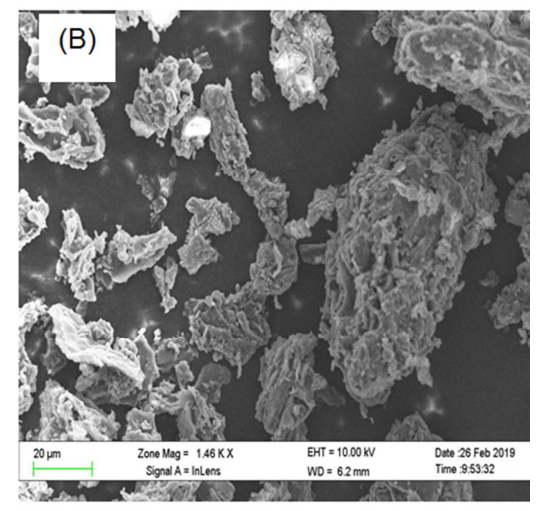

Figure 1. A- FTIR spectrum of AC; $B$ - SEM image of $A C$.

\subsection{Effect of Solution pH and Adsorption Mechanism}

In this study, the initial $\mathrm{pH}$ of the atrazine solution was varied from 2 to 10 and the results obtained were shown in Figure 2A. Analysis of results indicated that the removal efficiency of atrazine decreased from $87.56 \%$ to $77 \%$ with increase in the $\mathrm{pH}$ from 2 to 10 . Moreover, the zero-point charge $\left(\mathrm{pH}_{\mathrm{ZPC}}\right)$ of $\mathrm{AC}$ was 3.2 [15]. Accordingly, at $\mathrm{pH}<3.2$ the functional groups of AC surface were positively loaded and at $\mathrm{pH}>3.2$ the surface of $\mathrm{AC}$ became negatively charged. Atrazine molecule is a weak base with pKa of 1.7 , thus, at $\mathrm{pH}<1.7$, the molecules of atrazine are protonated and the atrazine molecules get positively loaded. At $\mathrm{pH}>1.7$, the surface of atrazine became negative loaded through excess of hydroxide ion from the solution. Therefore, the adsorption of atrazine may be due to hydrogen bonds established between the surface of activated carbon and the nitrogen atoms from atrazine molecules. Furthermore, atrazine structure shown $\pi$ electrons, so, atrazine has a hydrophobic character. AC also owned a hydrophobic property due to its lignin content [14]. Thus, $\pi-\pi$ interactions would be established between the atrazine molecules and the surface of the activated carbon. At $\mathrm{pH}$ value range 1.7-3.2, the attraction electrostatic interaction occurred between the positive loads from AC surface and the negative loads from atrazine molecule, which justified high adsorption value observed (Figure 2A). The decrease in adsorption of atrazine with $\mathrm{pH}>3.2$ may be explained by the repulsion electrostatic interaction between the both negative charged particles. From results in Figure 2A, the high adsorption efficiency of atrazine was reached at $\mathrm{pH}=2$. But, in this work, the experiments were conducted at $\mathrm{pH}=5$ because the natural $\mathrm{pH}$ value of atrazine solution was around 5 , which was in accordance with $\mathrm{pH}$ value reported by Kumar et al. [22]. Finally, the proposed mechanism for atrazine adsorption onto $\mathrm{AC}$ was presented in Figure 2B.
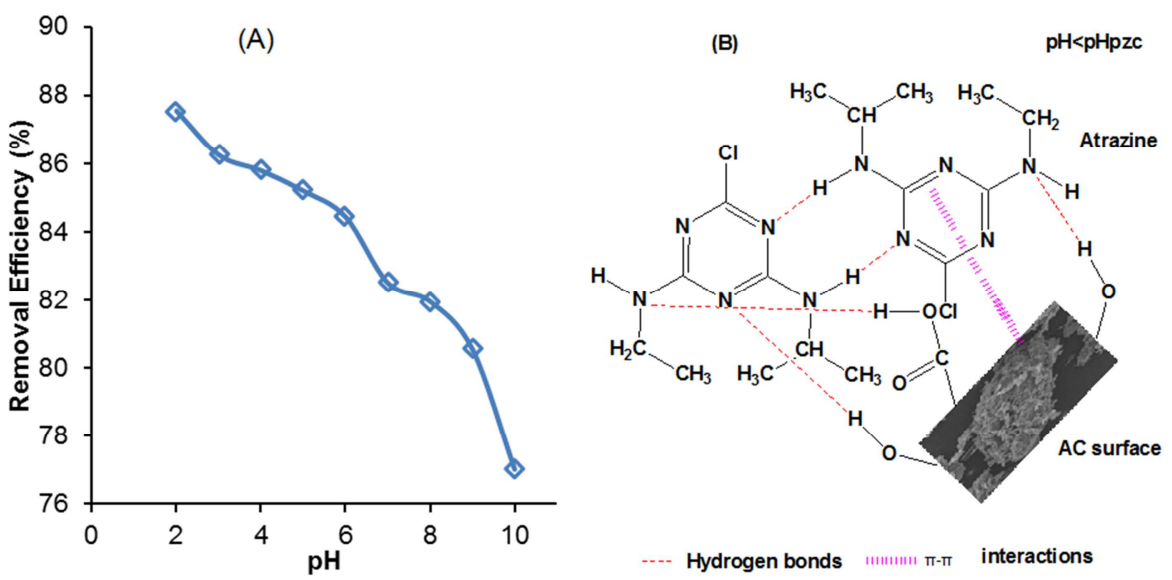

Figure 2. A-Effect of solution $p H$; B-Mechanism of atrazine adsorption. 
The effects of the contact time were carried out in the time range $0-120 \mathrm{~min}$ with $50 \mathrm{~mL}$ of $50 \mathrm{mg} / \mathrm{L}$ of atrazine solution at $\mathrm{pH} \mathrm{5,7}$ and 9 and at room temperature. The results presented in Figure 3A shown that the removal percentage of atrazine increased with increase in the contact time from 0 to $120 \mathrm{~min}$. The adsorption was fast at early of the process and became slow around $60 \mathrm{~min}$ in the contact time. Indeed, at the start of the reaction, there are a large number of available active sites on AC surface. As the contact time increased, the active sites from AC surface were gradually filled with the atrazine molecules, which led to a depletion in available sites for adsorption and resulted to equilibrium state noted in Figure $3 \mathrm{~A}$. The results also revealed that the equilibrium time was $60 \mathrm{~min}$, however, in order to ensure that equilibrium was reached for all essays performed, a contact time of $120 \mathrm{~min}$ was chosen as equilibrium time, which was in accordance with those reported by Ghosh and Shirmardi et al. [23, 24]. In
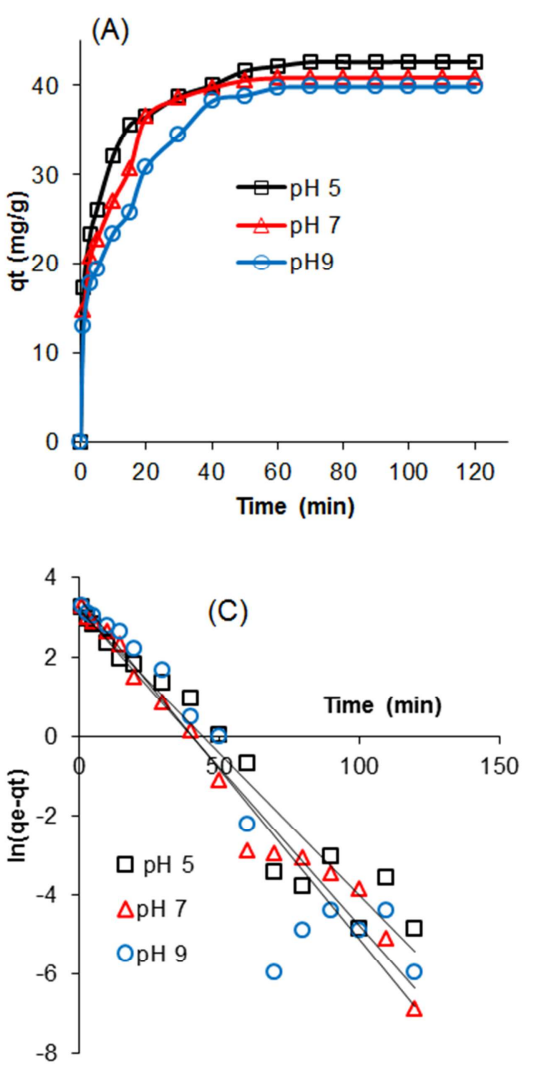

\subsection{Effects of Contact Time and Kinetic Study}

order to describe the adsorption mechanism, the kinetic models of pseudo-first-order, pseudo-second-order and intraparticle diffusion were studied. The plots of the kinetics models and the kinetic parameters were presented in Figure 3 (B, C, D) and Table 1. It is seen from the results in Table 1 that the pseudo-second order model well followed the experimental results with correlation coefficient $\mathrm{R}^{2}$ greater than 0.99 for the three $\mathrm{pH}$ values tested. The experimental adsorption capacities were also in best agreement with those calculated. The plots of the intraparticle diffusion model (Figure 3D) presented two linear portions, indicating that the adsorption process happened in two stages. The first step was fast because the pores of the adsorbent were available at the start of the process, while the second step was slow and suggested the pores saturation. In addition, none of the linear portions passed through the abscissa origin, hence, the intraparticle diffusion model involved in the adsorption of atrazine.
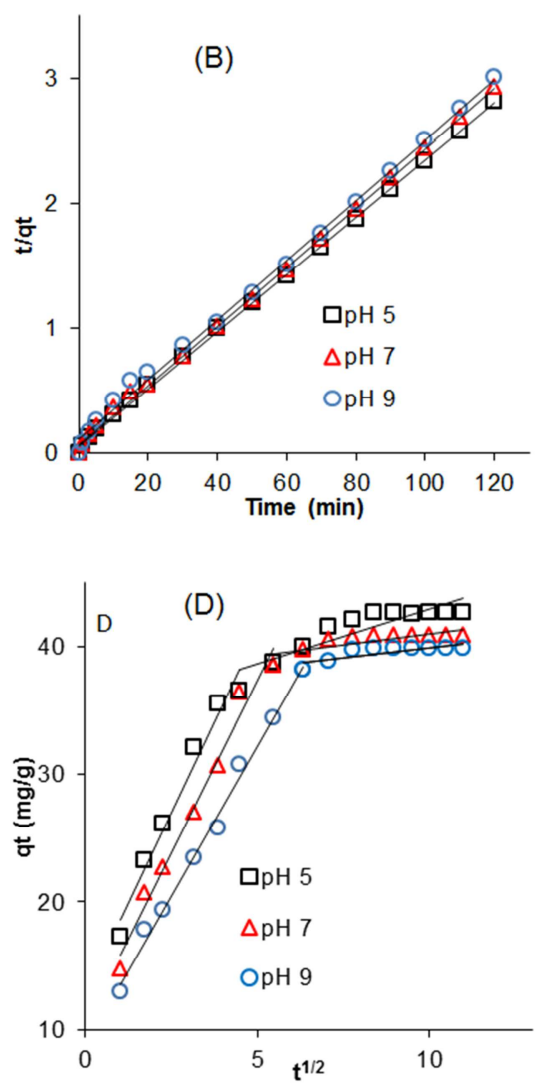

Figure 3. A-Effect of contact time, B - pseudo-second-order model, $C$ - pseudo-first-order model, D - intraparticle diffusion model.

Table 1. Kinetic parameters.

\begin{tabular}{lllll}
\hline & & $\mathbf{p H}=\mathbf{5}$ & $\mathbf{p H}=\mathbf{7}$ & $\mathbf{p H = 9}$ \\
\hline & $\mathrm{q}_{\text {eexp }}(\mathrm{mg} / \mathrm{g})$ & 42.63 & 40.88 & 39.84 \\
& $\mathrm{q}_{\text {ecal }}(\mathrm{mg} / \mathrm{g})$ & 24.24 & 24.63 & 22.26 \\
Pseudo-first-order & $\mathrm{k}_{1}\left(\mathrm{~min}^{-1}\right)$ & 0.071 & 0.079 & 0.086 \\
& $\mathrm{R}^{2}$ & 0.94 & 0.97 & 0.903 \\
& $\mathrm{q}_{\text {ecal }}(\mathrm{mg} / \mathrm{g})$ & 45.45 & 43.47 & 43.47 \\
Pseudo-second-order & $\mathrm{k}_{2}(\mathrm{~g} / \mathrm{mg} / \mathrm{min})$ & 0.0079 & 0.0074 & 0.0047 \\
& $\mathrm{R}^{2}$ & 0.999 & 0.998 & 0.997 \\
\hline
\end{tabular}




\begin{tabular}{llllllll}
\hline & & Fist step & Second step & Fist step & Second step & Fist step & Second step \\
\hline \multirow{3}{*}{ Intra-particle } & $\mathrm{C}(\mathrm{mg} / \mathrm{g})$ & 12.97 & 34.34 & 10.43 & 37.66 & 8.840 & 36.95 \\
& $\mathrm{k}_{\text {id }}\left(\mathrm{mg} / \mathrm{g} / \mathrm{min}^{-1 / 2}\right)$ & 5.641 & 0.861 & 5.368 & 0.331 & 4.675 & 0.293 \\
& $\mathrm{R}^{2}$ & 0.973 & 0.785 & 0.980 & 0.626 & 0.993 & 0.622 \\
\hline
\end{tabular}

\subsection{Adsorption Isotherm Study}

Langmuir, Freundlich and Temkin isotherms were studied to better understand the mechanism of atrazine adsorption. The obtained results and the isotherm parameters were shown in Figure 4 and Table 2. The results from Figure 4A revealed that the adsorption capacities of AC increased with increase in the atrazine concentration due to the growth in the driving force from the concentration gradient [25]. In addition, the results also denoted that the adsorption capacity decreased with increasing in the $\mathrm{pH}$ due to the electrostatic repulsion between the $\mathrm{AC}$ surface and the atrazine molecules. Moreover the results in the table 2 indicated that the adsorption of atrazine on AC may be described by Langmuir isotherm at $\mathrm{pH} 5,7$ and 9 . The values of the separation factor $\mathrm{R}_{\mathrm{L}}$ of Langmuir model were all less than 1 , suggesting that the adsorption process of atrazine onto AC was
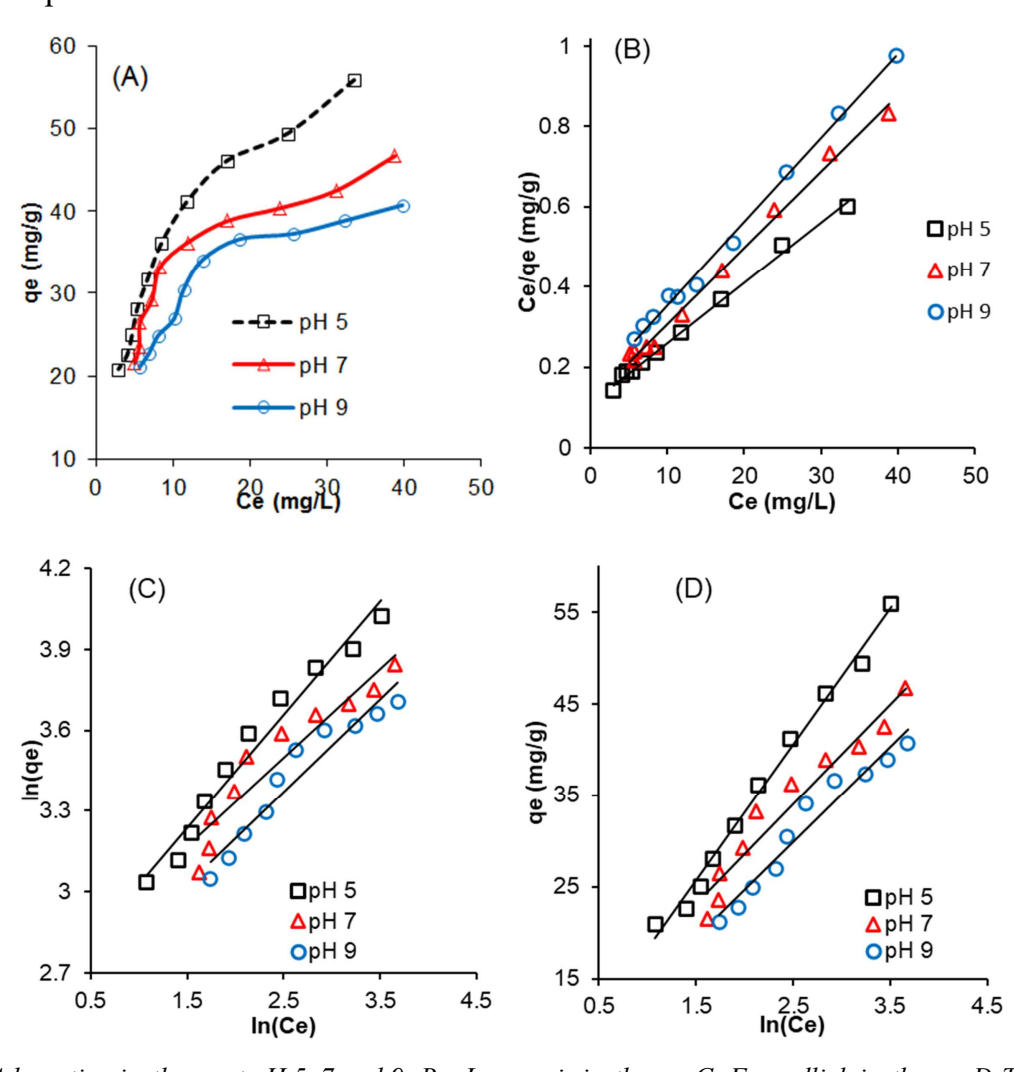

Figure 4. A-Adsorption isotherm at pH 5, 7 and 9; B-Langmuir isotherm; C-Freundlich isotherm; D-Temkin isotherm.

Table 2. Isotherm parameters of atrazine adsorption.

\begin{tabular}{|c|c|c|c|c|}
\hline & & $\mathrm{pH}=5$ & $\mathbf{p H}=7$ & $\mathbf{p H}=\mathbf{9}$ \\
\hline \multirow{3}{*}{ Langmuir } & $\mathrm{q}_{\mathrm{m}}(\mathrm{mg} / \mathrm{g})$ & 66.66 & 52.63 & 48.08 \\
\hline & $\mathrm{K}_{\mathrm{L}}(\mathrm{L} / \mathrm{mg})$ & 0.134 & 0.162 & 0.141 \\
\hline & $\mathrm{R}^{2}$ & 0.995 & 0.993 & 0.995 \\
\hline \multirow{3}{*}{ Freundlich } & $\mathrm{n}$ & 2.392 & 3.048 & 2.923 \\
\hline & $\mathrm{K}_{\mathrm{f}}\left(\mathrm{mg} / \mathrm{g}(\mathrm{L} / \mathrm{mg})^{1 / \mathrm{n}}\right)$ & 13.585 & 14.541 & 12.366 \\
\hline & $\mathrm{R}^{2}$ & 0.970 & 0.898 & 0.923 \\
\hline \multirow{3}{*}{ Temkin } & $\mathrm{b}_{\mathrm{T}}\left(\mathrm{J} \cdot \mathrm{mol}^{-1}\right)$ & 14.88 & 10.89 & 10.41 \\
\hline & $\mathrm{A}_{\mathrm{T}}(\mathrm{L} / \mathrm{mg})$ & 1.244 & 1.875 & 1.440 \\
\hline & $\mathrm{R}^{2}$ & 0.990 & 0.944 & 0.950 \\
\hline
\end{tabular}

normal and occurred with appearance of monolayers. The values of $\mathrm{n}$ constant from Freundlich isotherm were also included between 1 and 10, indicating a normal adsorption. The values of the $b_{\mathrm{T}}$ constant from the Temkin isotherm were low, which suggested that the adsorption process was less energetic. The low values of $\mathrm{A}_{\mathrm{T}}(1.244,1.875,1.440 \mathrm{~L} / \mathrm{mg})$ suggested also the physisorption nature of the adsorption process. The values of the maximum capacities calculated according to the Langmuir isotherm were $66.66,52.63$ and $48.08 \mathrm{mg} / \mathrm{g}$ at $\mathrm{pH} 5,7$ and 9 respectively. Finally, the adsorption capacity at $\mathrm{pH} 5$ was compared with those of various adsorbents reported in the literature (Table 3). The results pointed out a significant performance of prepared $\mathrm{AC}$ for atrazine removal compared to other adsorbents. Thereby, the peanut shell activated carbon can be used as efficient adsorbent for atrazine. 
Table 3. Adsorption capacities of various activated carbons.

\begin{tabular}{lllll}
\hline Adsorbent & $\mathbf{q}_{\mathbf{m}}(\mathbf{m g} /)$ & $\mathbf{p H}$ & Contact time $(\mathbf{h})$ & $\mathbf{T}\left({ }^{\circ} \mathbf{C}\right)$ \\
\hline Desert Date Seed Shell Activated Carbon & 3.235 & 7 & neferences & 25 \\
Activated peanut husk & 4.12 & na & 3 & 25 \\
Granular carbon & 5.0 & 5 & 24 & 14 \\
Activated carbon & 13.95 & 6 & 2 & 25 \\
Peanut shell activated carbon & 66.66 & 5 & 2 & 25 \\
\hline
\end{tabular}

na: not available

\section{Conclusion}

The results of this study revealed that the peanut shell activated carbon shown high adsorption potential toward atrazine. The pseudo-second-order kinetic well described the adsorption process than the pseudo-first-order model. The equilibrium data at different $\mathrm{pH}$ were best fitted to Langmuir isotherm model. The maximum adsorption capacity 66.66 $\mathrm{mg} / \mathrm{g}$ determined at $\mathrm{pH} 5$ and at $30^{\circ} \mathrm{C}$ was significantly higher than of numerous adsorbents reported in literature. Therefore, the prepared activated carbon could be used as efficient adsorbent for atrazine and other pesticides removal from contaminated water.

\section{Acknowledgements}

The authors gratefully acknowledge the Administration authorities of "Ecole Normale Supérieure" (ENS) of Natitingou, Benin for the research financing.

\section{References}

[1] Pimentel, D., (2009). Pesticides and pest control: Integrated Pest Management: Innovation-Development Process. Vol. 1, Springer, Chap. 3, pp. 83-87.

[2] Lage, A. L. A., Ribeiro, J. M., Souza-Fagundes, E. M., Brugnera, M. F., da Silva Martins, D. C., (2019). Efficient atrazine degradation catalyzed by manganese porphyrins: Determination of atrazine degradation products and their toxicity evaluation by human blood cells test models. Journal of Hazardous Materials. 378, 120748.

[3] Sun, J. T., Pan, L. L., Tsang, D. C. W., Zhu, L. Z., Li, X. D., (2017). Atrazine contamination in agricultural soils from the Yangtze River Delta of China and associated health risks. Environmental Geochemistry and Health. 39, 369-378.

[4] Jiang, Z., Li, J., Jiang, D., Gao, Y., Chen, Y., Wang, W., Cao, B., Tao, Y., Wang, L., Zhang, Y., (2020). Removal of atrazine by biochar-supported zero-valent iron catalyzed persulfate oxidation: Reactivity, radical production and transformation pathway. Environmental Research. 184, 109260.

[5] Mahlalela, L. C., Casado, C., Marugan, J., Septien, S., Ndlovu, T., Dlamini, L. N., (2020). Photocatalytic degradation of atrazine in aqueous solution using hyperbranched polyethyleneimine templated morphologies of $\mathrm{BiVO}_{4}$ fused with $\mathrm{Bi}_{2} \mathrm{O}_{3}$. Journal of Environmental Chemical Engineering. 8,10425 .

[6] Pinto, C. F., Antonelli, R., de Arujo, K. S., de Toledo, A. L. F., Fernandes, D. M., Granato, A. C., Azevedo, E. B., Malpass,
G. R. P., (2019). Experimental-design-guided approach for the removal of atrazine by sono-electrochemical-UV-chlorine techniques. Environmental Technology. 40 (4), 430-440.

[7] Fengyue, S., Xiangwei, Y., Yongqiang, M., Yiqiang, L., (2019). Rapid removal of triazine pesticides by P-doped biochar and the adsorption mechanism. Chemosphere. 235, 918-925.

[8] Giwa, S. O., Moses, J. S., Adeyi, A. A., Giwa, A., (2018). Adsorption of Atrazine from Aqueous Solution Using Desert Date Seed Shell Activated Carbon. Journal of Engineering Research and Development. 1 (3), 317-325.

[9] Murilo, B. A., Tassia, R. T., Santos, M. F. S., Marcelo, F. V., Hamoudi, R. B. S., (2019). Graphene oxide impregnated with iron oxide nanoparticles for the removal of atrazine from the aqueous medium. Separation Science and Technology. 54, 2653-2670.

[10] Ali, I., Al-Othman, Z., Al-Warthan, A. (2016). Sorption kinetics and thermodynamics studies of atrazine herbicide removal from water using iron nano-composite material. International Journal of Environmental Science and Technology. 13: 733-742.

[11] Coldebella, P. F., Klen, M. R. F., Nishi, L., Valverde, K. C., Cavalcanti, E. B., dos Santos, O. A. A., Bergamasco, R., (2017). Potential Effect of Chemical and Thermal Treatment on the Kinetics, Equilibrium, and Thermodynamic Studies for Atrazine Biosorption by the Moringa oleifera Pods. Canadian Journal of Chemical Engineering. 95, 961-973.

[12] Cusioli, L. F., de Oliveira, C. B., Quesada, H. B., Baptista, A. T. A., Nishi, L., Vieira, M. F., Bergamasco, R., (2019). Modified Moringa oleifera Lam Seed husks as low-cost biosorbent for atrazine removal. Environmental Technology, DOI: $10.1080 / 09593330.2019 .1653381$.

[13] Ho, Y. S., Chiang, T. H., Hsueh, Y. M., (2005). Removal of basic dye from aqueous solution using tree fern as a biosorbent. Process Biochemistry. 40, 119-124.

[14] Saha, A., Bhaduri, D., Pipariya, A., Ghosh, R. K., (2017). Linear and Nonlinear Sorption Modelling for Adsorption of Atrazine onto Activated Peanut Husk. Environmental Progress \& Sustainable Energy. 36, 348-358.

[15] Fatombi, J. K., Agani, I., Osseni, A. S., Idohou, A. E., Neumeyer, D., Verelst, M., Maurico, R., Aminou, T., (2020). Influence of salts and humic acid on 2,4dichlorophenoxyacetic acid removing from aqueous solution by peanut shell activated carbon. Desalination and Water Treatment. 189, 250-263.

[16] Lagergren, K., Svenska, A., (1898). The theory of so-called adsorption of soluble substances. Veten skapsaka demiens Handlingar. 24, 1-39.

[17] Ho, Y. S., McKay, G., (1999). Pseudo-second-order model for sorption processes. Process Biochemistry. 34, 451-465. 
[18] Weber, W. J., Morris, J. C., (1963). Kinetics of adsorption on carbon from solution. Journal of Sanitation Engineering Division. 89, 31-60.

[19] Langmuir, I., (1919). The adsorption of gases on plane surfaces of glass, Mica and Platinum. Journal of American Chemistry Society. 40, 1361-1403.

[20] Freundlich, H., Heller, W., (1939). The adsorption of cis-and transazobenzene. Journal of American Chemistry Society. 61, 2228-2230.

[21] Temkin, M. I., Bakh, A. N., (1934). Adsorption of hydrogen by palladium in the presence and absence of water. Journal of Physic and Chemistry. 5, 809.

[22] Kumar, Y. B., Singh, N., Singh, S. B. (2013). Removal of atrazine, metribuzin, metolachlor and alachlor by granular carbon. Journal of Environmental and Analytical Toxicology. 3, 3-7.

[23] Shirmardi, M., Alavi, N., Limae, E. C., Takdastan, A., Mahvi, A. H., Babaeif, A. A., (2016). Removal of atrazine as an organic micro-pollutant from aqueous solutions: a comparative study. Process Safety and Environmental Protection. 103, 23-35.

[24] Ghosh, R. K., Philip, L., (2005). Performance evaluation of waste activated carbon on atrazine removal from contaminated water. Journal of Environmental Science Health Part B. 40, 425-441.

[25] N'Diaye, A. D., Boudokhane, C., Kankou, M., Dhaouadi, H., (2019). Potential of rice husk ash in atrazine removal. Chemistry and Ecology. 35 (7), 678-692. 